\title{
SINERGI SUPPLY CHAIN YANG EFEKTIF : LITERATURE REVIEW AGROINDUSTRI BAWANG MERAH DI SUMATERA BARAT
}

\section{SYNERGI AND EFFECTIVE SUPPLY CHAIN : LITERATURE REVIEW AGROINDUSTRY SHALLOT IN WEST SUMATERA}

\author{
Dedet Deperiky $^{1,2)}$, Santosa ${ }^{3)}$, Rika Ampuh Hadiguna ${ }^{3)}$, Nofialdi ${ }^{3)}$ \\ ${ }^{1)}$ Universitas Mohammad Natsir Bukittinggi, Sumatera Barat \\ Jln. Tan Malaka Bukit Cangang/Belakang Balok, Bukittinggi, Sumatera Barat \\ 2) Mahasiswa Program Doktor Teknologi Industri Pertanian, Pasca Sarjana, Universitas Andalas, Padang, Indonesia \\ Email : dedve.lpdp@umnyarsi.ac.id, deverikysupplychain@gmail.com \\ ${ }^{3)}$ Program Studi Ilmu Pertanian, Pemusatan Teknologi Industri Pertanian, Pasca Sarjana Universitas Andalas, Padang, Indonesia
}

Makalah: Diterima 12 September 2018; Diperbaiki 29 April 2019; Disetujui 10 Mei 2019

\begin{abstract}
The agroindustry of shallot in West Sumatra currently requires further strengthening of the relationship between supply chain actors to improve the efficiency of the market system and the application of modern technology today. This study aimed to map the supply chain of shallot agroindustry in West Sumatra and reconstruct the synergy of shallot agroindustry supply chain actors for the welfare of farmers. The research methodology used the Systematic Literature Review (SLR), i.e. literature review method which identify, assess, and interpret all findings on a research topic, to answer research question. The results of the study showed that the portrait of shallot agroindustry supply chain was mapping the market potential that is a mainstay in shallot agroindustry, conducting comparative analysis of the role of stakeholders in the supply chain as a business unit, mapping gaps in profit distribution among supply chain actors, and accurating recorded price data. Farmers had a high ability in market access and integrated in all business processes with all supply chain stakeholders. In conclusion, synergi of supply chain on integrated shallot agroindustry will correlated to the increasing ability of the resources supply chain shallot agents of agroindustry from various elements and to integrate a more efficient and effective supply chain that transforms the agricultural sector into the industrial sector.
\end{abstract}

Keywords: supply chain, agroindustry, synergi, agriculture sector

\section{ABSTRAK}

Agroindustri bawang merah di Sumatera Barat saat ini membutuhkan penguatan lebih lanjut dari hubungan antara pelaku supply chain untuk meningkatkan efisiensi sistem pasar dan penerapan teknologi modern saat ini. Penelitian ini bertujuan untuk memotret rantai pasok agroindustri bawang merah di Sumatera Barat dan merekonstruksi sinergi pelaku rantai pasok agroindustri bawang merah untuk kesejahteraan petani. Metodologi penelitian yang digunakan adalah metode Systematic Literature Review (SLR) yaitu metode literature review yang menelaah, merangkum, dan menginterpretasi seluruh penemuan masalah pada suatu topik penelitian, untuk menjawab serta menganalisis pertanyaan pada penelitian (research question). Hasil penelitian bahwa potret rantai pasok agroindustri bawang merah adalah memetakan potensi pasar yang menjadi andalan dalam agroindustri bawang merah, melakukan analisis komparatif terhadap peran stakeholders dalam rantai pasok sebagai unit bisnis, memetakan kesenjangan dalam distribusi keuntungan diantara pelaku rantai pasok dan mengakurasikan data harga yang dicatat. Sinergi pelaku supply chain itu tidak dapat berdiri sendiri tetapi harus dikelola bersama sama dengan fungsi lainnya dalam rantai yang terkoordinasi. Pada hakikatnya, agroindustri bawang merah melihat aspek pada petani sebagai subjek yang intinya petani sejahtera dan mempunyai kemampuan tinggi dalam akses pasar dan terintegrasi pada semua proses bisnis dengan semua pemangku kepentingan supply chain. Kesimpulannya, sinergi supply chain pada agroindustri bawang merah akan berkorelasi pada peningkatan kemampuan sumber daya pelaku rantai pasok agroindustri bawang merah dari berbagai elemen serta menghasilkan supply chain yang lebih efisiensi dan efektif dalam mentransformasi sektor pertanian ke sektor industri.

Kata kunci: supply chain, agroindustri, sinergi, sektor pertanian

\section{PENDAHULUAN}

Bawang merah merupakan sayuran rempah yang dikonsumsi setiap orang di dunia. Hal ini dapat dipahami bahwa sebagian besar penduduk dunia mengkonsumsi bawang merah, sementara penduduk yang mengkonsumsi bawang merah sangat relatif terbatas, dengan kondisi tersebut maka data dunia khusus tentang bawang merah sulit dijumpai, data yang ada adalah produksi bawang secara keseluruhan Menurut data Food And Agriculture Organization of The United Nation (2017) bahwa China merupakan produsen bawang merah terbesar di dunia yang kemudian di produksi 
juga oleh beberapa negara di Benua Eropa dan Amerika. Melihat data FAO (2017) produsen dan konsumen bawang merah yang terbesar di ASEAN adalah Indonesia. Beberapa Negara di ASEAN seperti Myanmar, Thailand, dan Phillipina juga memproduksi bawang merah namun tidak sebesar produksi di Indonesia. Dengan kondisi tersebut maka beberapa negara di ASEAN yang memproduksikan bawang merah banyak ditujukan dalam rangka ekspor ke negara-negara yang produksi bawang merah yang tergolong rendah. Produksi bawang merah dunia dapat dilihat pada Tabel 1.

Tabel 1. Produksi bawang merah dunia tahun 2017

\begin{tabular}{clc}
\hline No & Negara & Produksi (Ton) \\
\hline 1 & China & $23,849,053$ \\
2 & India & $19,415,425$ \\
3 & Mesir & $3,115,482$ \\
4 & USA & $3,025,700$ \\
5 & Iran & $2,345,768$ \\
6 & Belanda & $2,120,581$ \\
7 & Indonesia & $1,446,869$ \\
8 & Republik Korea & $1,298,749$ \\
9 & Spanyol & $1,254,697$ \\
10 & Jepang & $1,243,000$ \\
11 & Uzbekistan & $1,184,863$ \\
12 & Myanmar & $1,170,874$ \\
\hline
\end{tabular}

Menurut data Kementrian Pertanian (2015), Indonesia adalah negara berbasis pertanian yang memiliki sumber daya alam yang beragam dan mempunyai wilayah pertanian yang sangat luas. Hal ini yang menjadikan Indonesia sebagai salah satu negara penghasil bawang merah terbesar di dunia. Di negara agraria, pertanian memiliki peranan yang sangat strategis di bidang perekonomian ataupun pemenuhan kebutuhan pangan. Indonesia merupakan salah satu dari beberapa negara berkembang dengan sektor pertanian sebagai sumber penghasilan utama dari mayoritas penduduknya sebagai petani. Artinya, sebagian besar masyarakat di bidang pertanian mengantungkan hidupnya pada sektor pertanian. Optimalisasi pemanfaatan lahan di wilayah Indonesia sebagian besar diperuntukkan sebagai lahan pertanian (Kementan, 2015). Di Indonesia bawang merah telah ditanam di berbagai propinsi, mulai dari Aceh sampai ke Papua. Pada tahun 2015, Provinsi Sumatera Barat memproduksi bawang merah yang tertinggi di Sumatera yaitu 32.442 ton. Kalau diamati pertumbuhan luas panen bawang merah di Sumatera Barat semenjak tahun 2008 sampai dengan 2015 mencapai kenaikan 9,88\%. Produksi bawang merah di Indonesia dapat dilihat pada Tabel 2.

Jika kita lihat kondisi diatas bahwa rantai pasok agroindustri bawang merah juga sudah menjadi perhatian utama para pelaku agroindustri. Ina (2015) penerapan konsep manajemen rantai pasok pada sektor agroindustri dikenal dengan istilah manajemen rantai pasok pada agroindustri tidak berbeda dengan dengan sektor manufaktur pada umumnya. Namun demikian, pencirian khusus agroindustri yakni, bulki, seasonable dan perishable memberikan pengaruh yang sangat berarti pada hal pembangunan dan pengembangan berbagi konsep manajemen rantai pasok.

Menurut Hadiguna (2015), bahwa kunci keberhasilan dari sistem rantai pasok agroindustri adalah bahan baku. Agroindustri membutuhkan pasokan bahan baku yang bermutu dan jumlah yang sesuai dengan kebutuhan tetapi dihadapkan pada kondisi musiman dan perishable. Rantai pasok agroindustri secara sederhana adalah urutan dalam sebuah rangkaian yang terdiri dari pemasok, pemroses, distributor atau pengecer dan konsumen dengan bahan baku utamanya adalah komoditas pertanian terentu. Manajemen rantai pasok agroindustri adalah sebuah pendekatan yang diterapkan untuk mengelola komoditas pertanian tertentu dimulai dari pemasok sampai konsumen untuk menciptakan nilai tertentu dari produk olahan yang memperhatikan kontribusi dari pelaku disepanjang rantai pasok secara proposional dan berkeadilan.

Tabel 2. Produksi bawang merah Provinsi di Indonesia tahun 2017

\begin{tabular}{clcc}
\hline No & \multicolumn{1}{c}{ Provinsi } & Produksi (Ton) & Persen \\
\hline 1 & Jawa Tengah & 506.357 & 48,27 \\
2 & Jawa Timur & 203.739 & 19,42 \\
3 & Jawa Barat & 116.396 & 11,10 \\
4 & NTB & 104.324 & 9,95 \\
5 & Sumatera Barat & 32.442 & 2,39 \\
6 & Sulawesi Selatan & 23.276 & 2,22 \\
7 & DI Yokyakarta & 19.951 & 1,90 \\
8 & Bali & 10.981 & 1,05 \\
9 & Sulawesi Tengah & 10.301 & 0,98 \\
10 & Sumatera Utara & 9.413 & 0,90 \\
11 & Propinsi Lainnya & 19.138 & 1,82 \\
\hline & Indonesia & 1.446 .869 & 100 \\
\hline
\end{tabular}


Rantai pasok agroindustri banyak melibatkan pihak diantaranya petani, pedagang pengepul, agroindustri, distributor, pengecer dan pihak terkait tidak langsung lainnya. Manajemen rantai pasok agroindustri sebenarnya menggunakan pendekatan yang berkemampuan holistik dalam mewujudkan sebuah agroindustri yang handal, efektif dan efiseiensi. Disamping itu, prinsip proposionalitas yang sangat diharapkan pada sistem pertanian modern dapat dicapai melalui praktek manajemen rantai pasok. Hal ini dapat dilakukan karena konsep pendekatan manajemen rantai pasok agroindustri mengedepankan pemenuhan kepuasaan para pemangku kepentingan. Dalam sistem rantai pasok agroindustri para pemangku kepentingan mempunyai kepentingan dan tujuan yang berbeda beda, sehingga setiap pemangku kepentingan memilki kepentingan yag berbeda dan dipengaruhi pula oleh lingkungan bisnis. Cara pandang yang holistik dan tidak menghilangkan kompleksitas sangat penting diperhatikan (Hadiguna, 2015).

Supply chain agroindustri mengikutsertakan sekumpulan stakeholders, mulai dari tingkat petani hingga ke tingkat konsumen akhir. Namun karena kurangnya sistem kolektifitas secara berkelanjutan oleh petani, sehingga banyak stakeholders dan aliran transaksi yang harus dimulai terlebih dahulu, hal ini tentu berdampak pada harga produk yang tinggi terhadap produksi pertanian (Herawati, 2015). Masalah yang mendasar bagi petani adalah keterbatasan petani dalam melakukan penetapan harga jual. Bergaining Power petani pada saat ini umumnya masih sangat lemah, hal ini dikarenakan pada kendala usaha peningkatan pendapatan petani. Tidak kuatnya daya tawar petani pada dasarnya disebabkan para petani kurang mendapatkan akses informasi pasar pada sistem rantai pasok pertanian.

Panjangnya mata rantai pasok pertanian saat ini menjadi momok yang menakutkan bagi petani untuk dapat terus melangkah maju dan mengoptimalkan produk pertanian terutama untuk pangan yang sehat dan high quality. Selain itu, tingginya biaya produksi, transportasi, biaya logistik juga ketergantungan kebutuhan pupuk akan pabrik industri juga menjadi hambatan tersendiri dalam proses supply chain agroindustri dalam hal manajemen distribusi. Hal ini dikarenakan proses supply chain yang panjang dari petani kecil ke pedagang, sehingga banyak para pedagang menjadi pengendali kebijakan harga dalam supply chain pertanian, mereka berperan sebagai aktor penentu harga terhadap hasil produk petani kecil. Selain itu, petani kecil masih dipersulit dengan beberapa hambatan yang menghambat sistem pemasaran produknya, sehingga proses distribusi produk pertanian belum seluruhnya berjalan baik dan ketidakberdayaan petani dalam ketatnya persaingan di pasar nasional maupun internasional (Danil 2014; Ambe 2014). Selama ini petani kecil, masih melakukan sistem tradisional dalam mengoptimalkan produksinya. Hal ini sangat berpengaruh terhadap komoditas panen yang dihasilkan, karena produk pertanian yang juga bersifat cepat rusak dan mudah busuk (perishable) serta musiman . Ketika panen datang, ketersedian produk sangat banyak dan harga jual pun bisa turun drastis dengan nilai produk yang sangat rendah, sedangkan pada saat belum terjadi pada kondisi musiman, ketersediaan barang menjadi langka sehingga menyebabkan harga jual bisa diatas harga pasar. Ketersediaan produk yang tidak stabil seperti ini menjadi tantangan besar petani, sehingga petani tidak bisa memenuhi permintaan pasar secara berkesinambungan.

\section{METODE PENELITIAN}

Metode penelitian yang dipakai adalah dengan metode systematic literature review atau sering disingkat SLR. Metode ini menelaah, merangkum, dan menginterpretasi seluruh penemuan masalah pada suatu topik penelitian serta menjawab pertanyaan penelitian yang telah ditetapkan sebelumnya (Kitchenham dan Charters, 2017). Metode SLR dilakukan secara sistematis dengan mengikuti tahapan awal pada proses literature review sehingga terhindar dari pemahaman yang bersifat bias dan subjektif dari penelitinya. Gambar 1 menjelaskan bahwa metode systematic literature review adalah pendekatan sistematis pada metodologi penelitian, sementara itu pada metode traditional review tidak menggunakan metode penelitian yang berdasarkan kepada kemauan (inklinasi) penulis

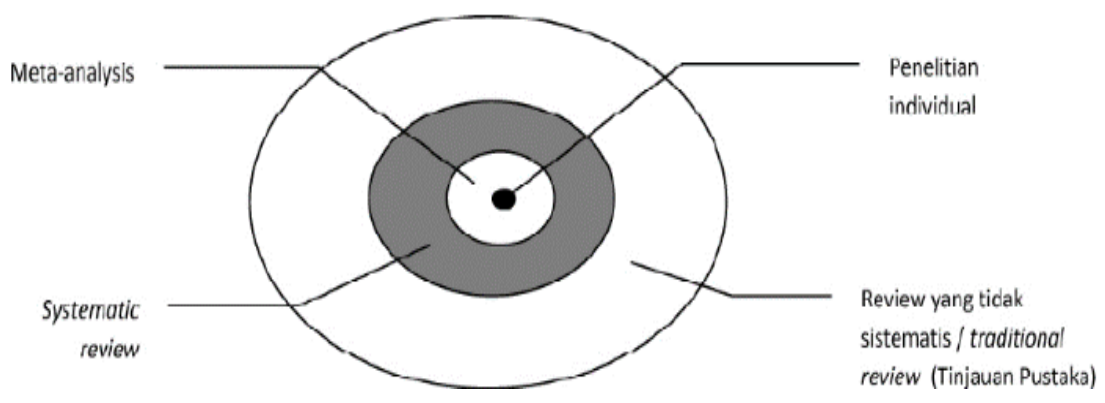

Gambar 1. Metode Systematic Literature Review 
Beberapa tulisan dalam metode ilmiah traditional review adalah studi kepustakaan. Seperti pada konsep metode penelitian, pada dasarnya penelitian systematic literature review dimulai dengan membuat hipotesa awal, systematic literature review dan tahapan selanjutnya adalah dengan melakukan penelitian systematic literature review. Analogi dengan metode penelitian secara umum, di mana dalam systematic literature review terdapat metode quantitative dan qualitative. (Okoli, 2017; Kusumadewi, 2010).

Metode pada pendekatan quantitative systematic literature review digunakan untuk mensintesa rangkuman penelitian dengan pendekatan statistik. Misalnya, Randomized Control Trials (RCT), Cohort Study, Case-Control Study, atau studi prevalensi. Pada metode ini dalam merangkum sintesa hasil penelitian disebut dengan "meta-analisis". Secara pengertian, bahwa metode melakukan agregasi review untuk mendapatkan nilai kemampuan statistik (statistical power) dalam mengidentifikasi hubungan causal-effect antara faktor risiko dengan hasil (outcome) (Okoli, 2017; Dostaller, 2013).

Pada pendekatan qualitative systematic literature review dipakai pada mensintesa hasil temuan beberapa penelitian yang bersifat pada data sekunder. Merangkum tentang hasil beberapa penelitian qualitative ini disebut "meta-sintesa". Meta-sintesa adalah teknik pada menyatukan persepsi data untuk menemukan teori baru untuk meningkatkan pemahaman yang lebih radikal dan menyeluruh (Okoli, 2017).

\section{HASIL DAN PEMBAHASAN}

\section{Potret Rantai Pasok Agroindustri Bawang Merah}

Pada prinsipnya, rantai pasok pertanian memiliki dua tipe, yaitu produk segar dan produk yang diproses. Produk segar dapat berupa buah, sayuran, dan sejenisnya yang tidak membutuhkan proses pengolahan khusus atau proses transformasi kimia. Produk pertanian yang diproses membutuhkan proses transformasi kimia atau perubahan bentuk. Rantai pasok untuk produk pertanian yang diproses akan melibatkan beberapa pemain, di antaranya petani atau perkebunan, pengolah atau pabrik, distributor, dan pengecer (retail). Setiap perusahaan diposisikan dalam sebuah lapisan jaringan dan keterlibatan minimal satu rantai pasok. Dalam jaringan rantai pasok pertanian, lebih dari satu rantai pasok dan lebih dari satu proses bisnis yang dapat diidentifikasi (Tompudung, 2016; Golan, 2011; Kogan, 2016).

Dalam satu waktu, proses paralel dan berurutan dapat terjadi dalam rantai pasok pertanian, jika rantai pasok pada umumnya didefinisikan sebagai sistem consumer-driven, maka rantai pasok pertanian dapat didefinisikan sebagai sistem producer consumer-driven.
Peramalan permintaan dan pasokan mempunyai tingkat kepentingan yang sama dalam rantai pasok pertanian, tetapi anggota rantai pasok mempunyai kemampuan yang sangat sedikit dan terbatas untuk mengendalikannya.

Rantai pasok agroindustri juga cukup khas karena karakteristik bahan pertanian yang sangat sensitif terhadap waktu. Oleh karena itu, pengelolaan persediaan, transportasi, dan komponen rantai pasok lainnya perlu dirancang dengan memperhatikan karakteristik tersebut. Pembahasan rantai pasok pertanian kecil belum banyak dilakukan karena melihat kodisi komoditi pertanian mudah busuk dan cepat rusak sehingga untuk melakukan kajian ini diperlukan pemahaman yang sangat mendalam dan kajian rantai pasok pada umumnya dilakukan oleh para peneliti dengan latar belakang lmu manajemen atau keteknikan yang berbasis logam. Beberapa penelitian yang mengkaji lingkup rantai pasok pertanian antara lain karakteristik produk-produk pertanian yang sangat khas menyebabkan kompleksitas masalah rantai pasok menjadi meningkat.

Upaya untuk menjaga kestabilan harga produk hasil pertanian adalah dengan merekonstruksi sistem rantai pasok yang berpihak kepada petani kecil. Tidak hanya itu, competitive skill yang handal dari petani juga dibutuhkan sebagai strategi dalam mengupayakan memanajerial komoditas pertanian yang unggul agar dapat menciptakan produk yang dapat berkompetitif di pasar global dan memenuhi standar kualitas keamanan pangan, sehingga perlu dilakukan kemitraan dengan berbagai pihak untuk meminimalisir tingginya ongkos produksi baik dari pemerintah maupun stakeholders (Kembey, 2016; Mahsa, 2014; Al-Fawaeer, 2013). Upaya yang bisa dilakukan secara sinergi yaitu adalah perbaikan sarana dan prasarana, pembaharuan sejumlah peraturan, dan pembangunan sistem kelembagaan. Rekonstruksi sistem rantai pasok pertanian harus dikaji ulang lagi secara serius dan komprehensif. Pembuatan kebijakan ini jangan dipercayakan begitu saja kepada pelaku pasar yang bersifat oligopoly dan monopoli bahkan pada komoditas tertentu akan dikuasai oleh beberapa oknum pengambil kebijakan di dalam negeri maupun di luar negeri

Harga pasar tidak boleh bergantung kepada kebijakan harga asing karena tidak berhubungan secara signifikan terhadap biaya produksi dan profit (Cabigiosu, 2012; Nissen, 2011, Seethamraju, 2014). Harga harus berorientasi dengan biaya produksi dan profit petani serta batas kekuatan daya beli masyarakat. Harga harus dapat meminimalisir biaya produksi dan kemampuan petani sehingga tidak merugikan masyarakat. Aspek kelembagaan petani seperti koperasi yang memang berorientasi kepada kepentingan petani kecil serta pembangunan pada perdesaan hingga sekarang belum dilakukan secara optimal. Program yang menitikberatkan pada 
aspek keberlanjutan kelembagaan juga tidak optimal. Seyogyanya, beberapa hal untuk membangun sistem rantai pasok pada agroindustri yang harus dilakukan adalah Pertama, menata ulang sistem rantai pasok produk pertanian dengan cara mengidentifikasi potensi unggulan daerah yang menjadi point strategis dalam kawasan agroindustri pertanian. Pada sasarnya, potensi unggulan produk pertanian yang dimiliki suatu kawasan belum terkelola secara terpadu dan berkelanjutan.

Kedua, mengidentifikasi analisa komparatif terhadap peran serta stakeholders dalam rantai pasok sebagai unit bisnis. Karena saat ini, masih ditemukan gap dalam profit share diantara stakeholders rantai pasok dimana petani kecil menjadi pihak yang dirugikan dan memiliki risiko yang tinggi dibanding dengan pelaku rantai pasok lainnya. Ketiga, Data harga yang diakurasikan dan dicatat perlu ada suatu terobosan baru yang diharapkan mampu tercatat tentang perubahan harga antar waktu. Akan lebih optimal jika data pada sebuah lokasi bisa dibandingkan dengan lokasi lainnya, sehingga perubahan pada perilaku harga untuk skala yang lebih luas bisa dikontrol. Keempat, petani harus bisa mandiri dalam penyedian kebutuhan usaha tani dan tidak ketergantungan kepada rentenir dalam hal peminjaman dana untuk produksi.

Menurut Hadiguna (2015), ciri utama dari sistem rantai pasok agroindustri adalah komitmen dalam mengalirkan barang dari hulu sampai hilir. Kooperasi dan kolaborasi menjadi kata kunci dari efisiensi dan efektivitas dari rantai pasok. Kooperasi merupakan bentuk kerjasama antar pelau secara horizontal misalnya sesama petani. Kolaborasi adalah bentuk kerjasama antar pelaku secara vertikal, misalnya antara petani dengan koperasi. Penentuan rantai pasok perlu memperhatikan cakupan kompleksitas, memulai dari industri sendiri, pengorganisasian para petani dan transparansi infomasi dari kegiatan. Panjang rantai pasok dan supply chain size akan menetukan kesinambungan bisnis dan produk yang dihantarkan.Keterlibatan banyak pelaku dalam unit rantai pasok harus disesuaikan dengan kebutuhan kapasitas dan perkiraan permintaan (Pujawan, 2017)

\footnotetext{
Merekonstruksi Sinergi Pelaku Rantai Pasok Agroindustri Bawang Merah

Mengelola Supply Chain

Sebagian besar dari strategi harus fokus

pada perencanaan supply chain yang menguntungkan (Kogan 2015; Vorst 2007) menyelidiki bagaimana tim manajer dari perusahaan dalam supply chain dapat membantu untuk merumuskan rencana strategis operasi seluruh rantai, mendapatkan keuntungan setiap perusahaan dan menguntungkan seluruh rantai. Golan (2011) menyarankan bahwa kerangka kerja yang luas untuk menerapkan supply chain di suatu perusahaan. Ini terdiri dari perumusan strategi, identifikasi daerah
}

untuk meningkatkan aliran material, dan evaluasi kinerja akhirnya untuk menentukan seberapa baik inisiatif supply chain telah dilaksanakan.

\section{Menganalisis Supply Chain}

Pendekatan ini disajikan dalam memungkinkan peneliti dan praktisi untuk menganalisis masalah yang sebenarnya dihadapi dalam supply chain dan alat-alat yang diperlukan untuk mengatasi masalah ini. Rantung (2016) bahwa supply chain dieksplorasi, dianalisis, dan berasal tema umum tentang teknik penilaian risiko pasokan. Penelitian ini menunjukkan bahwa organisasi pembelian bisa menilai risiko pasokan dengan teknik yang berfokus pada mengatasi masalah kualitas pemasok, meningkatkan proses pemasok, dan mengurangi kemungkinan gangguan pasokan. Doran (2013) menganalisis sumber konflik antara pembeli dan penjual yang berkaitan dengan harga barang yang dibeli untuk digunakan dalam produksi. Penulis berpendapat bahwa konflik antara pembeli dan penjual adalah hasil yang tak terelakkan ketika pembeli membuat keputusan terutama berpusat pada penafsiran literal dari peran manajemen sebagai agen dewan yang bertanggung jawab utama adalah untuk memaksimalkan nilai pemegang saham. dengan menggunakan target costing sebagai alat untuk meningkatkan supply chain. Kebutuhan pelanggan dan hubungan supply chain diidentifikasi sebagai kriteria utama dalam supply chain untuk memilih metode yang paling tepat dari target costing untuk supply chain. Harga berbasis nilai, biaya manajemen berdasarkan aktivitas pendekatan untuk menargetkan biaya dibahas dan rekomendasi untuk mereka gunakan berdasarkan kebutuhan pelanggan dan hubungan supply chain yang ditawarkan (Nepal, 2012).

\section{Mengembangkan Supply Chain}

Fase ini tidak hanya mengidentifikasi pemasok handal tetapi juga mencakup pengembangan saling percaya, sistem informasi dan hubungan baik antara berbagai mitra. alam tahap ini konsep SCM diterapkan untuk mengembangkan metode pembayaran, pengiriman, pengiriman untuk menyediakan layanan pelanggan yang lebih baik. Wang (2014) membahas bahwa nilai kepercayaan dan efek dari investasi spesifik transaksi untuk tingkat relatif upaya bersama kolaboratif, dan juga untuk menilai efek moderasi dari jaringan informasi pada upaya bersama tersebut. Hal ini ditemukan bahwa jaringan informasi tidak memoderasi hubungan antara upaya bersama kepercayaan dan efek moderat signifikan dari jaringan pada hubungan antara investasi tertentu transaksi dan upaya Bersama (Akbar, 2013). Hasil penelitian menunjukkan bahwa pembeli marah investasi khusus mereka dengan tingkat upaya bersama sesuai dengan informasi yang diperoleh dalam jaringan. Haming (2014) menyimpulkan bahwa kolaborasi 
supply chain sulit untuk menerapkan; ketika ada perubahan pada teknologi, dan fundamental kurangnya kepercayaan antara mitra dagang. Disimpulkan bahwa pembeli harus mempertimbangkan hubungan dengan perusahaan mereka sendiri, pemasok yang ada dan pemasok baru, untuk membangun kepercayaan dan bersaing tujuan.

Integrasi Supply Chain
Tahap berikutnya dalam supply chain
adalah untuk mengintegrasikan supply chain membutuhkan integrasi semua kegiatan seperti sourcing, pengadaan, penjadwalan produksi, pemrosesan order, manajemen persediaan, transportasi, manufaktur, pergudangan dan layanan pelanggan. Ini membuktikan bahwa inisiatif perusahaan berbeda dengan tujuan merekadan mengusulkan kerangka kerja untuk melambangkan inisiatif integrasi perusahaan berdasarkan kemampuan organisasi yang disajikan dalam model proses bisnis yang terintegrasi, yang menyoroti pentingnya komunikasi antara proses dan antara mitra dalam supply chain (Nissen, 2011).

\section{Sinergi Supply Chain}

Al-Fawaeer (2013) menjelaskan bahwa sinergi pada supply chain memperoleh sejumlah pedoman manajerial untuk menggunakan pemasaran dan variabel strategi operasional untuk mempengaruhi parameter reaksi sehingga memperoleh manfaat maksimal dari pelaku rantai pasok dan pasar. Selanjutnya penulis menekankan perlunya fokus pada kemampuan sumber daya manusia, harga dari kegiatan daripada produk, dan penggunaan informasi tentang perilaku konsumen.

Produk yang digunakan adalah cara inovatif dalam manajemen kembali dari titik ekonomi dan lingkungan pandang dan mempelajari sistem pemulihan produk di mana produsen produk-produk asli bergerak dalam remanufaktur digunakan produk diambil kembali dari pelanggan dalam konteks tanggung jawab produk diperpanjang. Selain itu diselidiki apa orientasi keuntungan sejauh dalam manajemen pemulihan produk akan merangsang perilaku sadar lingkungan di produsen (Doran, 2013). Gambar 2 menyajikan Logframe literature review sinergi supply chain agroindustri yang efektif.

\section{KESIMPULAN DAN SARAN}

\section{Kesimpulan}

Berdasarkan hasil penelitian dapat disimpulkan bahwa potret pada proses pembentukan rantai pasok agroindustri bawang merah pada pengelolaannya dapat dipandang sebagai sebuah transformasi organisasi dari sistem konvensional kepada sistem baru. Banyak hasil penelitian yang memanfaatkan kajian terhadap rantai pasok yang berhasil daripada yang telah gagal. Pengetahuan tentang bagaimana sebuah rantai pasok dan logistik itu tidak berjalan, bagaimanapun, dapat membantu pengembangan strategi untuk meminimumkan resiko, membantu dalam memperbaiki rantai pasok yang pernah tidak berjalan, dan mencegahnya dari kegagalan yang lebih dalam.

Terdapat peningkatan perhatian di sektor bisnis tentang dampak peningkatan lingkungan pasar kompetitif dan jenis-jenis pengelolaan yang adaptif yang dibutuhkan untuk berhasil dalam lingkungan dinamis dan berubah tersebut. Dengan demikian, keberhasilan dalam supply chain agroindustri ditentukan oleh tingkat keberhasilan dalam membangun dan mempertahankan kerjasama dan aliansi (kontrak), yang merupakan konsep dasar utama dalam rantai pasok agroindustri (Mahsa, 2014). Rantai pasok agroindustri bergantung pada sinergi antar pelaku rantai pasok dan interaksi bisnis terkait produk, jasa, sumberdaya keuangan dan informasi. Rantai pasok bertujuan untuk mensinergikan hubungan antar pelaku rantai pasok, yang berarti menciptakan cara-cara yang terorganisir. Rantai pasok untuk berinteraksi satu sama lain bergantung kepada konsensus dari para pelaku yang terlibat dalam membangun hubungan dalam sistem tersebut. Beberapa jurnal penelitian ini mendefinisikan konsep, manajer, keadaan alam, sifat bahan pertanian dan pengembangan supply chain pada usaha agroindustri menunjukkan bahwa ada penelitian intensif yang harus dilakukan di seluruh dunia dalam bidang ini khususnya dalam bidang agroindustri.

\section{Saran}

Perlu dilakukan penelitian lebih lanjut tentang sinergi supply chain pada agroindustri bawang merah yang terintegrasi pada peningkatan kemampuan sumber daya dan organisasi pelaku rantai pasok agroindustri bawang merah yang lebih efisiensi dan efektif dalam mentransformasi sektor pertanian ke sektor industri.

\section{UCAPAN TERIMA KASIH}

Penulis mengucapkan terimakasih kepada Program Pascasarjana S3 Ilmu Pertanian Pemusatan Teknologi Industri Pertanian Pasca Sarjana Universitas Andalas, Promotor dan Co-Promotor Komisi Pembimbing, dan Beasiswa Lembaga Pengelola Dana Pendidikan (LPDP) Kementrian Keuangan dan Kementrian Riset Teknologi Pendidikan Tinggi yang telah mendukung penelitian pada Seminar Nasional Departemen Teknologi Industri Pertanian IPB tahun 2018. 


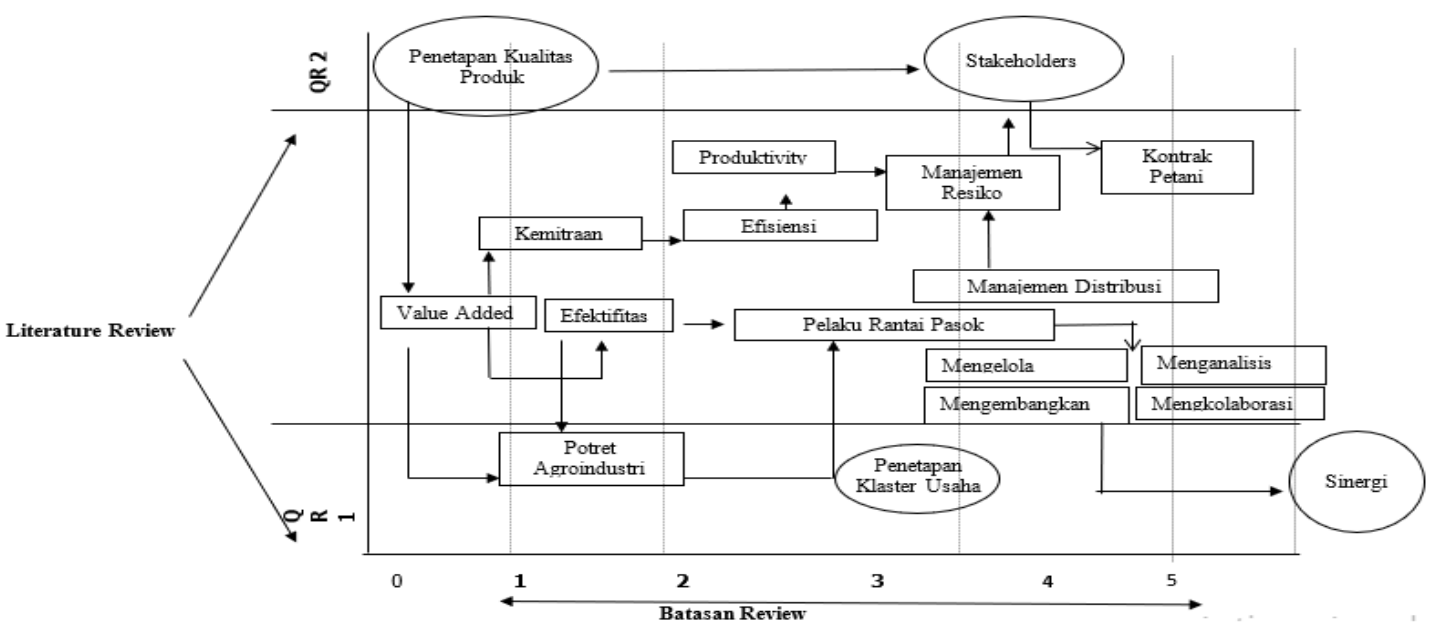

Gambar 2 : Logframe literature review sinergi supply chain agroindustri yang efektif

\section{DAFTAR PUSTAKA}

Akbar MD, Rahman A, Trantika CFM. 2013. Optimalisasi Aliran Distribusi dan Alokasi Material dengan Metode Linear Programming (Studi Kasus: PT. PLN (PERSERO) APJ Distribusi Malang). Jurnal Rekayasan dan Manajemen Sistem Industri. 1 (2): 403-414.

Al-Fawaeer M, Alhunity S, dan Al-Onizar H. 2013. The Impact of Information Technology in Enhancing Supply Chain Performance: An Applied Study on the Textile Companiesin Jordan. Research Journal of Finance and Accounting, Vol.4, No.8

Ambe IM. 2014. Key Indicators for Optimising SC Performance. The Case of Light vehicle manufacturers in South Africa. The Journal Applied Business Research. 30 (1) : 277-290.

Cabigiosu A, Zirpoli F, dan Camuffo A 2012. Modularity, Interfaces Definition and The Integration of External Sources of Innovation in The Automotive Industry. Research Policy, 42: 662-675.

Danil MF dan Hartoyo S. 2014. Produksi dan Pemasaran kako di kabupaten padang pariaman. Provinsi Sumatera Barat. Jurnal Manajemen \& Agribisnis. 11 (1) ; 41-52

Doran D. 2013. Supply chain implication of modularization. International Journal of Operations \& Production Management. 23 (3): 316-326.

Dostaller I. 2013. Competing in the global aerospace supply chain: the case of the canadian aerospace industry. Springer Science. 6 (2) :32-43.

[FAO] Food and Agriculture Organization. 2017. United Nation.
Golan E dan Mitchell L. 2011. Economics of food labeling. Journal Consumer Policy. 24: 117-184.

Hadiguna RA. 2015. Manajemen Rantai Pasok Agroindustri. Padang: Andalas University Press.

Haming D. 2014. Manajemen Produksi Modern : Operasi Manufactur dan Jasa. Edisi Ketiga. Jakarta : Penerbit Bumi Aksara.

Herawati. 2015. Kinerja dan efisiensi rantai pasok biji kakao di kabupaten Pasaman, Sumatera Barat. J TIDP. 2(1): 43-50.

Ina AR. 2015. Risiko rantai pasok agroindustri salak menggunakan fuzzy FMEA. [Tesis]. Bogor: Institut Pertanian Bogor.

Kambey SF, Kawet L, dan Sumarauw JSB. 2016. Analisis Rantai Pasokan (Supply Chain) Kubis Di Kelurahan Rurukan Kota Tomohon. Jurnal Riset Ekonomi, Manajemen, Bisnis dan Akuntansi.4 (5) : 303-408.

[Kementan] Kementrian Pertanian Republik Indonesia. 2015. Rencana Kerja Strategis Renstra Kementrian Pertanian

Kitchenham L dan Charters M. 2017. Systemic Litetarure Review. Int $J$ Software Engineering Group School of Computer Science and Mathematics. 52 (2017): 792805.

Kogan K dan Tapiero C. 2015. Coordination of coinvestments in supply chain infrastructure.Springer Science. 23:24712475.

Kusumadewi. 2010. Aplikasi Logika Fuzzy Untuk Pendukung Keputusan. Edisi-2 Jakarta. Graha Ilmu.

Mahsa P, Zamani S, dan Farzianpour F. 2014. Development of factors effective in the success of green supply chain management. American Journal Agricultural and Biological Sciences. 9 (1): 33-34. 
Nepal B. Monplaisir L, Famuyiwa O. 2012. Matching product architecture with supply chain design. European Journal of Operational Research. $216: 312-325$.

Nissen ME. 2011. Agent-Based Supply Chain Integration. Kluwer Academic Publishers. Manufactured in The Netherlands. 2: 289312.

Okoli C. 2017. A Guide to Conducting a Standalone Systematic Literature Review. Communications of the Association for Information Systems. 37 : 879-910.

Pujawan IN. 2017. Supply Chain Management. Edisi Ketiga. Yokyakarta: Penerbit ANDI.

Rantung ML, Adolfina P, Wenas RS. 2016. Analisis kinerja rantai pasok komoditas kacang tanah di pasar tradisional beriman kota Tomohon. Jurnal Riset Ekonomi, Manajemen, Bisnis dan Akuntansi. 4 (2): 768-892.

Seethamraju R. 2014. Enterprise systems and demand chain management: A crosssectional field study. Springer Science. 15:151-161.
Tompodung E, Worang FG, Roring F. 2016. Analisis Rantai Pasok (Supply Chain) ikan mujair Di Kecamatan Eris Kabupaten Minahasa. Jurnal Riset Ekonomi, Manajemen, Bisnis dan Akuntansi. 4 (3). 279-290.

Vorst JG, Van Der AJ, Silva CAD, Trienkens JH 2007. Agroindustrial Supply Chain Management : Concepts and Application Agricultural Management, Marketing and Finance Occasional Paper. Roma : Food and Agriculture Organization of The United Nations.

Wang Y, Wallace SW, Shen B, Choi TM. 2014. Service supply chain management: a review of operational model. European Journal of Operational Research. Collaboration. Gadjah Mada International Journal of Business. 11 (2): 685-698. 